\title{
Lectures
}

Les comptes rendus, 2016

Ramses Delafontaine

\section{Eric Cline, 1177 B.C. The year civilization collapsed.}

\begin{abstract}
Avertissement
Le contenu de ce site relève de la législation française sur la propriété intellectuelle et est la propriété exclusive de l'éditeur.

Les œuvres figurant sur ce site peuvent être consultées et reproduites sur un support papier ou numérique sous réserve qu'elles soient strictement réservées à un usage soit personnel, soit scientifique ou pédagogique excluant toute exploitation commerciale. La reproduction devra obligatoirement mentionner l'éditeur, le nom de la revue, l'auteur et la référence du document.

Toute autre reproduction est interdite sauf accord préalable de l'éditeur, en dehors des cas prévus par la législation en vigueur en France.
\end{abstract}

\section{revues.org}

Revues.org est un portail de revues en sciences humaines et sociales développé par le Cléo, Centre pour l'édition électronique ouverte (CNRS, EHESS, UP, UAPV).

\section{Référence électronique}

Ramses Delafontaine, « Eric Cline, 1177 B.C. The year civilization collapsed. », Lectures [En ligne], Les comptes rendus, 2016, mis en ligne le 01 février 2016, consulté le 11 février 2016. URL : http://lectures.revues.org/20004

Éditeur : Liens Socio

http://lectures.revues.org

http://www.revues.org

Document accessible en ligne sur :

http://lectures.revues.org/20004

Document généré automatiquement le 11 février 2016

(c) Lectures - Toute reproduction interdite sans autorisation explicite de la rédaction / Any replication is submitted to the authorization of the editors 


\section{Ramses Delafontaine}

\section{Eric Cline, 1177 B.C. The year civilization collapsed.}

In the final decades of the $12^{\text {th }}$ century B.C. a number of centuries-old empires in the Eastern Mediterranean collapsed. The notable exception being Egypt whose pharaohs defeated subsequent threats from the invading Sea Peoples. The end of the Bronze Age was characterised by the loss of many large state structures, population decline, the devastation or abandonment of many cities, and the disappearance of writing in large parts of the region. Braudel mentions in his Méditerranée that the Eastern Mediterranean at the end of the $12^{\text {th }}$ century B.C. 'returned to a level zero history, or close to it. ${ }^{11}$ In 1177 B.C. Eric Cline seeks to find out who or what was responsible for this collapse of civilization. The cyclical theory of historical change that follows a pattern of birth, rise and fall has been a very popular theme in Western historiography. In particular, Jared Diamond's 1995 book Collapse has reinvigorated the theme among American historians. In his book Cline discusses the rise and fall of several empires in the Eastern Mediterranean. He starts in the $15^{\text {th }}$ century B.C. and ends in the final decades of the $12^{\text {th }}$ century B.C.

The author devotes the largest part of his book - three of five chapters - to a world that will be lost. Cline introduces the principal players of the region one by one: Egyptians, Mitannians, Hittites, Minoans, Mycenaeans, Assyrians, Kassites/Babylonians, Cypriots, and Canaanites. All these civilizations are engaged in a complex international network focused on trade and diplomacy. Ships and caravans transported raw materials, precious stones such as the famed lapis lazuli, and metals such as gold, copper and tin, in a world that stretched from Greece to the Persian Plateau and from the Dardanelles to Sudan. Information from archeological sites, underwater archeology, textual records, radiocarbon dating, architecture, pottery from different regions, and other aspects of material culture found at palaces provides ample evidence of these mercantile interactions.

Cline states that trading expeditions often had diplomatic goals. Traders from time to time appeared both as merchants and as diplomats before foreign courts. When engaging in diplomacy, merchant-diplomats came bearing gifts which served to cement and sustain political treaties. The archives at Amarna and other records tell us of regular interchanges of tribute, gifts, and even brides between kings. Examples of economic warfare such as embargoes and close control over trade through state-protected activities attest even more to the notion of a close interconnection between trade and diplomacy. The Bronze Age in the East Mediterranean represents for Cline a golden age of internationalism with substantial and sustained relations. He argues that 'most of the goods sent back and forth were most likely either perishable - and have since disappeared - or were raw materials that were immediately converted into other objects, such as weapons and jewelry'. Cline states that through the archeological lens with which we look at the Bronze Age we glimpse only a fragment of the scale on which trade was conducted. He overstates when he baptizes these interactions 'the first global world system' and on another occasion refers to them as 'a cosmopolitan and globalized world system such as has only rarely been seen before the current day'. ${ }^{2}$ Cline overstates because he does not discuss the scale of this trade network. Nor does he consider whether the system integrated or affected the multitude living outside of the palaces, or whether there were cultural or technological exchanges amongst the larger populaces. Considering the examples provided in the book, one has to conclude that the commercial network only involved the elites of these empires. This book would have strengthened its ability to make claims on a global world system by considering scale and the people outside of elite circles, a challenge which has already been taken up by others in the field. ${ }^{3}$

After establishing the rise of these civilizations as well as the existence of an international system of trade and diplomacy, Cline tackles the causes of the ensuing collapse. Although 
the Sea Peoples have served as the usual suspects, Cline shows that, up until now, we have been unable to point to a primary single cause that brought down these ancient civilizations. Cline offers a more complex causal explanation featuring a multitude of interconnected factors. The book moves from one contributing cause to the next in what Cline calls a perfect storm in which the Sea Peoples were but one disrupting force. Earthquakes and the fires which followed them, climate change, drought and subsequent famine, internal uprisings (although Cline never clearly defines their nature), as well as invading peoples, each played a role. The importance of the Sea Peoples seems to have been overstated in historiography as Cline presents a more nuanced and peaceful picture that depicts the Sea Peoples as making up different and subsequent waves of warrior-migrants possibly fleeing catastrophes in their own home regions. In several cases they occupied abandoned cities, indicating existing problems in already faltering states. Destruction of a certain number of coastal cities can reasonably be related to the Sea Peoples, yet a lot of the inland destruction can only be attributed to them with great difficulty. By demythologizing the role of the Sea Peoples Cline arrives at a more complex history of the fall of these civilizations, whose collapse did not happen overnight but whose strengths were gradually weakened by a series of disruptive events. In addition, the book argues that this progress did not always advance in a linear fashion. Cline provides examples of cities that were first abandoned and were later repopulated to a certain extent, concluding that although it is true that the demise of some cities was indeed sudden and at the hand of invading migrants, the overall collapse of these civilizations was neither sudden nor attributable to a single cause.

The main point of critique which can be levelled against this book is probably a result of thematic requirements. The book is the first in a series published by Princeton University Press entitled Turning points in ancient history. From the editor's introduction to the book one gathers that the aim of the series is to underline the continuity and similarities between the $12^{\text {th }}$ century B.C. and our present world. This explains why Cline from time to time employs the term globalized world system to describe the international system of trade and diplomacy. A term which indicates that the globalization constitutes several forms of complex intertwinement, the destruction of which would cause severe harm to the entities of this globalized system. In other words, in a globalized world the Aristotelian whole is greater than the sum of its parts. In contrast to today's globalized world, a collapse of the commercial system of the Late Bronze Age would not have had a noticeable effect on the individual strengths of these civilizations. The international system did not collapse before the civilizations but, as Cline shows on multiple occasions in the book, traders were often active up until the last moment before calamity hit their city. The system of trade and diplomacy survived as long as the elites survived, and not vice versa. The survival of the elites was much more dependent on the interaction with their people at home. Considering that the comparisons with our modern day world reappear on multiple occasions in the book, and that these connections seem in part to function as a legitimization for the book, an extra chapter exploring the consequences of naming the international system in the Bronze Age a globalized world system would not be unwarranted. Yet, there is a lesson in this book which does not lie in a specific comparison but in the abstract. As Clive himself writes: 'we should not think that our current world is invulnerable.' The story of the late Bronze Age gives us an excellent lesson in humility by focusing on the complexity of the world in which we live and the non-human powers such as climate change which still rule our fates.

Notwithstanding my earlier remarks, Cline's book is a well-written and well-researched work. Cline is a good storyteller, a quality all too often ignored in scientific publications. This book is a good introduction to more in depth studies. It makes good use of a longue durée overview strengthened by multiple microstudies. It stands out by offering a fresh synthesis of the state of the art on the Sea Peoples and the complex downfall of the civilizations of the Late Bronze Age in the Eastern Mediterranean and the Near East. 


\section{Notes}

1 Braudel Fernand, La Méditerranée. L'Espace et L'Histoire, Paris, Flammarion, 1985, p. 101.

2 The book offers a number of uneasy analogies with modern historical events that feel forced or haphazard. The Arab Spring, nation states, the Russian revolution, and the longest drive-by shooting in history.

3 For example see: Van De Mieroop Marc, The Eastern Mediterranean in the Age of Ramesses II, Malden MA, Wiley-Blackwell, 2007.

\section{Pour citer cet article}

\section{Référence électronique}

Ramses Delafontaine, «Eric Cline, 1177 B.C. The year civilization collapsed. », Lectures [En ligne], Les comptes rendus, 2016, mis en ligne le 01 février 2016, consulté le 11 février 2016. URL : http:// lectures.revues.org/20004

\section{À propos du rédacteur}

\section{Ramses Delafontaine}

Ramses Delafontaine is a FWO PhD-fellow at the history department of Ghent University. His PhD research is focused on the legal and judicial use of historical argumentation with special attention to the legal figure of the historian as an expert witness. His first monograph is entitled: Historians as expert judicial witnesses in tobacco litigation: a controversial legal practice which was published by Springer International Publishing in April 2015. Delafontaine's research combines philosophy of history, public history, and legal history. He is a member of the executive board of the International Network for Theory of History (INTH). Currently, he is continuing his research as a Fulbright visiting researcher at Stanford University. Personal website: www.thejudgeandthehistorian.ugent.be

\section{Droits d'auteur}

(C) Lectures - Toute reproduction interdite sans autorisation explicite de la rédaction / Any replication is submitted to the authorization of the editors 